$\sqrt{3}$

J. bio-sci. 20: 135-142, 2012

ISSN 1023-8654

http://www.banglajol.info/index.php/JBS/index

\title{
EFFECTS OF FEEDING AND FERTILIZATION ON THE GROWTH AND PRODUCTION OF PUNTIUS SOPHORE IN SEASONAL PONDS IN NATORE, BANGLADESH
}

\author{
B M Mostafa Kamal1, Md Istiaque Hossain²* , Md Mosaddequr Rahman², Md Abdul Mannan ${ }^{3}$, \\ Md Al-Amin Sarker 2 \\ ${ }^{1}$ Natore fish farm, Natore, Bangladesh \\ 2 Department of Fisheries, Faculty of Agriculture, University of Rajshahi, Rajshahi, Bangladesh, \\ ${ }^{3}$ Faculty of Fisheries, Bangladesh Agricultural University, Mymensingh 2202, Bangladesh
}

\begin{abstract}
Context: Local farmers believe that the seasonal ponds and ditches which can retain water for 4 to 6 months in a year cannot be utilized for fish production but in fact such waters hold tremendous potential for culture of small indigenous fish species.

Objectives: To evaluate the effects of fertilization and feeding in the growth and production of Puntius sophore culture in seasonal ponds.

Materials and Methods: Six ponds were used during this study under two treatments. Two treatments such as $T_{1}$ (only fertilizer) and $T_{2}$ (fertilization and supplementary feeding) were run in triplicate. $P$. sophore was stocked in the two treatments at the rate of 15500 ha $^{-1}$ after necessary pond preparation and fertilization.

Results: Important physico-chemical factors viz., temperature, transparency, pH dissolved oxygen and total hardness of two treatments were found within the productive ranges. Four groups of phytoplankton were found in the ponds namely Bacillariophyceae, Chlorophyceae, Cyanophyceae and Euglenophyceae and two groups of zooplankton viz. Crustacea and Rotifera. P. sophore successfully breed in both treatments. However, the number of fish harvested was 122135 ha $^{-1}$ in $\mathrm{T}_{1}$ and 113335 ha $^{-1}$ in $T_{2}$. Yet the total production was higher in $T_{2}\left(1091.40 \mathrm{~kg} \mathrm{ha}^{-1}\right)$ than in $T_{1}\left(842.72 \mathrm{~kg} \mathrm{ha}^{-1}\right)$ as the individuals found in $\mathrm{T}_{2}$ gained more weight than those in $\mathrm{T}_{1}$ reflecting the effects of regular feeding.
\end{abstract}

Conclusion: The study indicated that both fertilizer and feed based treatment was to improve more production than only fertilizer based treatment under seasonal pond conditions.

Key words: Growth and production, Puntius sophore, feeding and fertilization

\section{Introduction}

Rural people of many South Asian countries including Bangladesh, consume 56-73 species of SIS (Minkin 1993), among which Mola (Amblypharyngodon mola, Hamilton), Chela (Chela cachius, Hamilton) and Punti (Puntius sophore, Hamilton) are most commonly preferred (Ahmad et al. 2010). The pool barb Puntius sophore (Hamilton 1822) (Cyprinidae) is an indigenous small fish of Bangladesh distributed extensively throughout the Indian sub-continent including Bangladesh, Bhutan, India, Nepal, and Pakistan (Rahman 1989, Talwar \& Jhingran 1991, Menon 1999, Petr 1999) and is also reported from Afghanistan (Petr 1999), China (Talwar \& Jhingran 1991) and Myanmar (Oo 2002). As $P$. sophore inhabits rivers, streams, ponds, beels, floodplains, baors, haors in plains and sub-montane regions predominantly (Menon 1999, Craig et al. 2004), it is an important target species for small-scale fishers (Shafi \& Quddus 1982, Rahman 2005), who

\footnotetext{
* Corresponding author Email: bitanrubd@yahoo.com, bitan@ru.ac.bd
} 
use a variety of traditional fishing gear (Kibria \& Ahmed 2005). However, $P$. sophore is declining rapidly due to heavy fishing pressure, and in recent studies from the Indian waters is categorized as lower risk to near threatened in the Western Ghat (Balasundaram et al. 2000) and in Harike wetland, a Ramsar site (Dua \& Parkash 2009). This fish is a major source of animal protein and micronutrients in the diet of rural small-scale farmers (Roos et al. 2007). In addition, it is an important indigenous small fish species of Bangladesh and much famed food fish item (Rahman 2005) that can also be used as an aquarium fish (Froese \& Pauly 2011).

Considering the growing trend of aquaculture and importance of $P$. sophore in the diet and nutrition of rural people in Bangladesh, it is high time to consider $P$. sophore as an important aquaculture species. This species be cultured in seasonal water bodies and ditches where water stay for about 4 to 6 months (e.g. small seasonal ponds, ditches etc.).

Several studies on the $P$. sophore populations include the growth in the Jamuna River, Bangladesh (De Graff 2003), length-weight and length-length relationships in the Mathabhanga River, northwestern Bangladesh (Hossain et al. 2006) and population structure, LWR and LLR in the chalan beel (Rahman et al. 2012). However, to the best of the authors' knowledge there is no study in the literature describing the culture techniques of $P$. sophore in ponds. Subsequently, the objectives of this study aimed to describe the effects of feeding and fertilization in the growth and production of $P$. sophore in seasonal ponds.

\section{Materials and Methods}

The study was conducted for a period of 6 months from June 2011 to November 2011 in six fish ponds located at Fish Seed Multiplication Farm, Natore, Rajshahi. Experimental ponds were rectangular in shape with an area of $75 \mathrm{~m}^{2}$ each and average depth of 1.5 meters. Two treatments of each $\mathrm{T}_{1}$ and $\mathrm{T}_{2}$ were consisted with 3 replications. In $T_{1}$, only fertilization was done weekly and no supplementary feed was provided and $T_{2}$, both fertilization and supplementary feeding were provided. However, fish were stocked at the same rate in both treatments.

\section{Pond preparation:}

Before stocking, ponds were initially dried, and treated with lime at a rate of $200 \mathrm{~kg} \mathrm{ha}^{-1}$. Cow dung, Urea and Triple Super Phosphate (TSP) were used at a rate of $1235 \mathrm{~kg} \mathrm{ha}^{-1}, 50 \mathrm{~kg} \mathrm{ha}^{-1}$ and $15 \mathrm{~kg} \mathrm{ha}^{-1}$, respectively. The ponds were then filled up with water from deep pump. The ponds were then left for approximately two weeks in order to allow the development of healthy pond community.

\section{Analysis water quality parameters:}

Water quality parameters including water temperature, transparency, dissolved oxygen, $\mathrm{pH}$, and total hardness were analyzed fortnightly. Water temperature and dissolved oxygen of water were determined by a portable DO meter (YSI model 58), pH of water was determined with a pH meter (Jenway Model 3020). Total hardness was measured titrimetically following Stirling (1985). Transparency of water was determined with a secchi disc and a measuring scale.

\section{Plankton collection and enumeration:}

Water samples were taken from different areas and depths from each pond fortnightly. The concentrated planktonic samples were preserved in 5\% of formalin and stored in a small, sealed plastic bottle until examined. By using a Sedgwick- Rafter Cell, a $1 \mathrm{ml}$ sub sample of each sample was examined under a microscope (SWIFT, M4000-D). The plankton contents of water were calculated in percentage for each pond. Both qualitative and quantitative studies of plankton were performed in this study. 


\section{Fish stocking:}

Fish seeds of $P$. sophore were collected from the nearest Satni beel and carried to the experimental ponds using plastic bucket and canvas tank. Good condition fish seeds were used for this experiment. Fish seeds were acclimatized before stocking in the ponds. Each pond was stocked with $P$. sophore at the rate of 15500/ha.

\section{Fertilization and supplementary feeding:}

$T_{1}$ was fertilized weekly with cow-dung, Urea and TSP at a rate of $300 \mathrm{~kg} / \mathrm{ha}, 7.5 \mathrm{~kg} / \mathrm{ha}, 3 \mathrm{~kg} / \mathrm{ha}$, respectively. On the other hand, $T_{2}$ was fertilized fortnightly with cow-dung, Urea and TSP at the rates of $600 \mathrm{~kg} / \mathrm{ha}, 15$ $\mathrm{kgha}^{-1}$ and $6 \mathrm{kgha}^{-1}$ and rice bran was supplied as supplementary feed only in the treatment 02 at a rate of $150 \mathrm{~kg} / \mathrm{ha} /$ week.

\section{Fish sampling:}

To study the growth, 20 fishes from each of the ponds were caught fortnightly by a cast net. Total length and weight of fishes were measured carefully and overall body condition was inspected visually.

\section{Stomach contents analysis:}

The abdomen of the sampled fish was cut open and the gut contents were taken out carefully and then put into a clean petridish. Only the anterior portion of the digestive tract between the esophagus and the small intestine was used for the stomach content analysis as the food items in this portion of the digestive tract are least digested and mostly identifiable. Sampling method was designed following McCombish (1967), Mckechnie \& Fenner (1971) and Dewan et. Al. (199l). The gut contents were then diluted with distilled water to $5 \mathrm{ml} .1 \mathrm{ml}$ sub-sample from each sample was transferred by a pipette to a Sedgwich-Rafter Cell (SR-Cell). Using a binocular microscope (SWIFT M4000-D) and phase contrast facilities, all organisms found in 10 of the thousand cells chosen randomly were identified and counted carefully.

\section{Statistical analysis:}

Statistical analyses were performed using Microsoft $₫$ Excel-add-in-DDXL and SPSS software (Version-11.5). All statistical analyses were considered significant at $5 \%(p<0.05)$.

\section{Results}

\section{Water quality parameters:}

Water quality parameters with their minimum and maximum values, mean and standard error are given in Table 1. Water temperatures of both treatments were recorded during each sampling date. The water temperature ranged from $25.5^{\circ} \mathrm{C}$ to $32.6^{\circ} \mathrm{C}$ (mean $\pm \mathrm{SE}=29.9 \pm 0.79$ ) in $\mathrm{T}_{1}$ and $26^{\circ} \mathrm{C}$ to $31.7^{\circ} \mathrm{C}$ (mean $\pm \mathrm{SE}=$ $29.83 \pm 0.64) \mathrm{T}_{2}$. On the other hand, the transparency fluctuated between $19 \mathrm{~cm}$ and $49 \mathrm{~cm}$ (mean $\pm S E=$ $28.83 \pm 3.27$ ) in case of $T_{1}$ and $19 \mathrm{~cm}$ and $40 \mathrm{~cm}$ (mean $\left.\pm S E=28.83 \pm 2.77\right)$ in case of $T_{2}$. In addition, $\mathrm{pH}$ values ranged from 6.88 to $9.22($ mean $\pm S E=7.72 \pm 0.25)$ in $\mathrm{T}_{1}$ and 6.79 to 8.22 (mean $\left.\pm \mathrm{SE}=7.65 \pm 0.18\right)$ in $\mathrm{T}_{2}$. Furthermore, dissolved oxygen levels of two treatments were found to be varied between $4.25 \mathrm{mg} / 1$ and $9.8 \mathrm{mg} / 1$ (mean $\pm S E=7.26 \pm 1.04)$ for $T_{1}$ and $1.80 \mathrm{mg} / 1$ and $9.2 \mathrm{mg} / 1$ (mean $\left.\pm S E=5.57 \pm 0.99\right)$ for $T_{2}$. Moreover, total hardness varied from $35 \mathrm{mg} / \mathrm{l}$ to $58 \mathrm{mg} / \mathrm{l}\left(\right.$ mean $\pm S E=45.41 \pm 3.84$ ) in $\mathrm{T}_{1}$ and $30.03 \mathrm{mg} / \mathrm{l}$ to $103.30 \mathrm{mg} / \mathrm{l}$ (mean $\pm \mathrm{SE}=62.44 \pm 8.88$ ) in $\mathrm{T}_{2}$. No significant differences were found in water temperatures, transparency and $\mathrm{pH}$ values between two treatments. However, significant differences were found in dissolved oxygen and total hardness levels between 2 treatments. 
Table 1. Water quality parameters of fish ponds under two treatments during study period.

\begin{tabular}{lllllll}
\hline \multicolumn{1}{c}{ Water quality parameters } & \multicolumn{3}{c}{$\mathrm{T}_{1}$} & \multicolumn{2}{c}{$\mathrm{T}_{2}$} \\
& \multicolumn{1}{c}{ Min } & \multicolumn{1}{c}{ Max } & \multicolumn{1}{c}{ Mean $\pm \mathrm{SD}$} & \multicolumn{1}{c}{ Min } & \multicolumn{1}{c}{ Max } & Mean $\pm \mathrm{SD}$ \\
\hline Temperature $\left({ }^{\circ} \mathrm{C}\right)$ & 25.5 & 32.6 & $29.96 \pm 0.73$ & 26 & 31.7 & $29.83 \pm 0.64$ \\
Transparency $(\mathrm{cm})$ & 19 & 49 & $28.83 \pm 3.27$ & 19 & 40 & $28.83 \pm 2.77$ \\
$\mathrm{pH}$ & 6.88 & 9.22 & $7.72+0.25$ & 6.79 & 8.44 & $7.65 \pm 0.18$ \\
Dissolved oxygen $(\mathrm{mg} / 1)$ & 4.25 & 9.8 & $6.15 \pm 0.68$ & 1.80 & 9.2 & $5.57 \pm 0.99$ \\
Total hardness $(\mathrm{mg} / 1)$ & 35 & 58 & $45.41 \pm 3.84$ & 30.03 & 103.30 & $62.44 \pm 18.88$ \\
\hline
\end{tabular}

Min, Minimum; Max, Maximum; SD, Standard deviation

Plankton population:

The results of the qualitative and quantitative studies of plankton population of two treatments during the period of study are shown in Table 2.

Table 2. Generic status of plankton identified during study period.

\begin{tabular}{ll}
\hline Phytoplankton & \multicolumn{1}{c}{ Zooplankton } \\
\hline Bacillariophyceae & Crustacean \\
Navicola, Diatima, Cyelotella & $\begin{array}{c}\text { Nauplius, Diaphanosoma, } \\
\text { Cyclops, Daphnia }\end{array}$ \\
Euglenophyceae & Rotifera \\
Phacus & Keratella \\
Chlorophyceae & \\
Gonatozygon, Pediastrum, Chlorococcus, Tetraedron, Ankistrodeonnis, Scenedesmus, \\
Botryococcus, Trachelomonas, Characium, Chlorella, Clisterium, Surirella, Volvox \\
Cyanophyceae & \\
Anabaena, Aphanocapsa, Gloeotrichia, Microcystis, Oscillatoria & \\
& \\
\hline
\end{tabular}

28 genera under 6 plankton groups were identified during the study. 23 genera of Phytoplankton under 5 groups namely Bacillariophyceae (2), Chlorophyceae (15), Cyanophyceae (5) and Euglenophyceae (1) and five genera of Zooplankton under two groups viz. Crustacea (4), Rotifera (1) were found (Table 2). Total phytoplankton ranged from $0.02 \times 10^{4}$ (Euglenophyceae) to $1.62 \times 10^{4} / /$ (Chlorophyceae) in $\mathrm{T}_{1}$ and $0.04 \times 10^{4} / \mathrm{l}$ (Euglenophyceae) to $3.68 \times 10^{4} / /$ (Cyanophyceae) in $\mathrm{T}_{2}$ (Table 3). Zooplankton population fluctuated from $0.02 \times 10^{4} / /$ (Rotifera) to $0.04 \times 10^{4} / /$ (Crustacea) in $\mathrm{T}_{1}$ and $0.24 \times 10^{4} / /$ (Rotifera) to $0.44 \times 10^{4} / /$ (Crustacea) in $\mathrm{T}_{2}$ (Table 3). 
Table 3. Abundance of plankton $\left(\times 10^{4} / /\right)$ in pond water under two treatments

\begin{tabular}{lll}
\hline Plankton groups & \multicolumn{1}{c}{ Treatment-1 } & Treatment-2 \\
& & \\
Phytoplankton & $0.24( \pm 0.06)$ & $0.06( \pm 0.04)$ \\
Bacillariophyceae & $1.62( \pm 0.19)$ & $1.14( \pm 0.31)$ \\
Chlorophyceae & $1.12( \pm 0.26)$ & $3.68( \pm 1.84)$ \\
Cyanophyceae & $0.02( \pm 0.02)$ & $0.04( \pm 0.03)$ \\
Euglenophyceae & & \\
Zooplankton & $0.04( \pm 0.03)$ & $0.44( \pm 0.12)$ \\
Crustacea & $0.02( \pm 0.02)$ & $0.24( \pm 0.10)$ \\
Rotifera & & \\
\hline
\end{tabular}

Electivity indices:

The electivity indices were determined according to Ivlev (1961). Electivity indices indicate that, $P$. sophore preferred to ingest maximum genera of phytoplankton than zooplankton. The phytoplankton group Cyanophyceae was consumed in higher quantity in both $T_{1}(7.37 \%)$ and $T_{2}(9.80 \%)$ followed by Chlorophyceae (Table 4). However, in case of Zooplankton, Crustaceans were dominant than Rotifera and $P$. sophore was found to prefer Crustaceans than the Rotifera in both treatments.

Table 4. Electivity indices in $T_{1}$ and $T_{2}$ during study

\begin{tabular}{lcccccc}
\hline Phytoplankton & \multicolumn{3}{c}{ Treatment - } & \multicolumn{3}{c}{ Treatment - 2 } \\
& Pw\% & Fg\% & E & Pw\% & Fg\% & E \\
\hline Bacillariophyceae & 13.79 & 3.28 & -0.62 & 10.79 & 2.78 & -0.59 \\
Chlorophyceae & 31.3 & 7.21 & -0.62 & 28.28 & 5.33 & -0.68 \\
Cyanophyceae & 51.72 & 7.37 & -0.75 & 81.48 & 9.8 & -0.79 \\
Euglenophyceae & 03.45 & 0.49 & -0.75 & 04.25 & 0.65 & -0.73 \\
Crustacea & 06.89 & 0.98 & -0.75 & 03.95 & 0.80 & -0.66 \\
Rotifera & 04.17 & 0.54 & -0.77 & 02.85 & 0.32 & -0.80 \\
\hline
\end{tabular}

Growth and production of fish:

Production of $P$. sophore was found higher in $T_{2}$ than in $T_{1}$. Maximum total length and body weight were found as $8.9 \mathrm{~cm}$ and $9.8 \mathrm{~g}$ in $T_{1}$ and $11.5 \mathrm{~cm}$ and $24.7 \mathrm{~g}$ in $T_{2} . P$. sophore was found to breed in both treatments. Final number of fish in $T_{1}$ was $122135 \mathrm{ha}^{-1}$ and in $\mathrm{T}_{2}$ it was $113335 \mathrm{ha}^{-1}$. Total production was higher in $\mathrm{T}_{2}\left(1091.40 \mathrm{~kg} \mathrm{ha}^{-1}\right)$ than in $\mathrm{T}_{1}\left(842.72 \mathrm{~kg} \mathrm{ha}^{-1}\right)$ (Table 5). 
Table 5. Details of number and weight of fish at stocking and harvesting and net production in two treatments

\begin{tabular}{lcc}
\hline \multicolumn{1}{c}{ Parameters } & $\mathrm{T}_{1}$ & $\mathrm{~T}_{2}$ \\
\hline Number of fish stocked & 116 & 116 \\
Initial average weight of stocked fish (g) & 2.94 & 3.01 \\
Average weight (g) at harvest & 6.90 & 9.63 \\
Number of fish harvested & 916 & 850 \\
Total production (kg ha-1) & 842.72 & 1091.40 \\
\hline
\end{tabular}

\section{Discussion}

Indigenous small fish species are of great demand in the rural areas as well as in the urban markets. Indigenous small fish including the $P$. sophore contains high protein, macro and micro-nutrients sometimes even higher than Indian major carps (Roos et al. 2007). Small fish species play an important role in eliminating the protein deficiency of rural poor people of Bangladesh and it may also help to improve their socio-economic condition through proper and scientific culture of these small indigenous fish species. As a consequence, it is very important to develop the culture techniques for these species.

Aquaculture depends almost completely on water quality and suitable of aquatic environment, In turn, the quality of aquatic environment depends on physical, chemical, biological and meteorological factors. Water quality parameters like temperature, transparency, $\mathrm{pH}$, dissolved oxygen, total hardness and plankton population were measured during present study. Water temperature was found to be suitable for fish culture throughout the study period in both treatments. Significant differences were found in dissolved oxygen concentration and total hardness between the treatments. Dissolved oxygen level fluctuated more in $T_{2}$ than that in $T_{1}$. This could be attributed to the decomposition of supplementary food and fertilizer in the ponds of $\mathrm{T}_{2}$. Nonetheless, except for one month (November) in $T_{2}$, dissolved oxygen levels were within the suitable range (Boyd 1998). pH levels in both treatments varied from 6.79 to 9.22 which were within the suitable limits for fish culture (Swingle 1967). No significant differences were found in transparency between treatments and were within the suitable range for fish culture.

Present study revealed that $P$. sophore ingested various types of phytoplankton and zooplankton but preferred to consume phytoplankton more than zooplankton. Among phytoplankton $P$. sophore ingested Cyanophyceae in greater number followed by Chlorophyceae in both treatments. A small number of Crustacean and Rotifera were also consumed by the fish in both treatments. No previous information found on the food and feeding habit of $P$. sophore restraining the comparison with previous studies. Shafi and Quddus (1974) described the main food of Puntius stigma as cyclops, daphnia, crustacean larvae and plant debris. Moreover, Phaorm (1980) found that Puntius gonionotus feeds mainly on aquatic plants, grasses and algae.

The initial number of fish stocked was 15500 ha-1 $^{-1}$ in both treatments and the number of fish harvested was $122135 \mathrm{ha}^{-1}$ in $\mathrm{T}_{1}$ and $113335 \mathrm{ha}^{-1}$ in $\mathrm{T}_{2}$. P. sophore successfully bred in both treatments. The number of fish found in $T_{1}$ was higher than that of $T_{2}$. This could be due to the divergence in sex ratios between the fish stocked in both treatments. However, the average final weight of fish was higher in $T_{2}$ than that in $T_{1}$ which is a clear indication of the effects of regular feeding that was provided only in the $T_{2}$. Subsequently the total production of fish was found to be higher in $T_{2}$ than in $T_{1}$. However, there is no study found on the culture of 
P. sophore in the literature inhibiting the comparison. Thus this study will provide important baseline for further such studies. Nonetheless, Ameen et al. (1984) found the production of monoculture of Amblypharyngodon mola in miniponds as 1.75 tons ha-1 which is much higher than that found in this study. These differences could be attributed to the differences in growth rate among species and the level of management. Nevertheless, fish seeds of $P$. sophore are available and low cost. In addition, following extensive aquaculture good production is possible in the seasonal ponds which could be sufficient not only for family consumption but also could be a source of extra income.

\section{Conclusion}

In spite of having high nutritional and market value and culture potential especially in the seasonal ponds, indigenous small species are often ignored for aquaculture in Bangladesh. This study showed that the culture of $P$. sophore in seasonal ponds is possible using either fertilizer or in combination of fertilization and feeding with moderate productivity.

\section{Acknowledgement}

Authors would like to thank the office staffs of Fish Seed Multiplication Farm, Natore, Rajshahi, Bangladesh for their support during the study. Authors are also grateful to the department of Fisheries, University of Rajshahi, Bangladesh for providing laboratory facilities.

\section{References}

Ahmad SAS, Bart AN, Yi Y, Rakocy JE, Diana JS. 2010. The effect of the introduction of Nile tilapia (Oreochromis niloticus, L.) on small indigenous fish species (mola, Amblypharyngodon mola, Hamilton; chela, Chela cachius, Hamilton; punti, Puntius sophore, Hamilton). Aquac Res 41, 904-912. http://dx.doi.org/10.1111/i.13652109.2009.02372.x

Ameen M, Islam KR, Mustafa G. 1984. Indigenous small fish culture in mini-ponds. Bangladesh J Zool 12(1), 1-10.

Balasundaram C, Arumugam R, Murugan PB. 2000. Fish diversity of Kolli hills, Western Ghats, Salem district, Tamil Nadu. Zoos Print J 16, 403-406. http://dx.doi.org/10.11609/JoTT.ZPJ.16.1.403-6

Craig JF, Halls AS, Barr JJF, Bean CW. 2004. The Bangladesh floodplain fisheries. Fish Res 66, 271-286. http://dx.doi.org/10.1016/S0165-7836(03)00196-6

De Graff G. 2003. The flood pulse and growth of floodplain fish in Bangladesh. Fisheries Manage and Ecol 10, 1-7.

Dewan S, Wahab, MA, Beveridge MCM, Rahman MH, Sarkerr BK. 1991. Food selection, electivity and dietary overlap among planktivorous Chinese and Indian major carp fry and fingerlings grown in extensively managed raifell ponds in Bangladesh. Aquacult Fish Manage 22, 277 - 294.

Dua A, Parkash C. 2009. Distribution and abundance of fish populations in Harike wetland-A Ramsar site in India. J Environ Biol 30, 247-251.

Froese R, Pauly D (Eds). 2011. Fish base 2011. World Wide Web electronic publication. Available at: http://www.fishbase.org (accessed on 22 February 2011).

Hossain MY, Ahmed ZF, Leunda PM, Islam AKMR, Jasmine S, Oscoz J, Miranda R, Ohtomi J. 2006. Lengthweight and length-length relationships of some small indigenous fish species from the Mathabhanga River, southwestern Bangladesh. J Appl Ichthyol 22(4), 301-303. http://dx.doi.org/10.1111/.1439-0426.2006.00801.x

Kibria G, Ahmed KKU. 2005. Diversity of selective and nonselective fishing gear and their impact on inland fisheries in Bangladesh. NAGA, 28, 43-48. 
McCombish TS. 1967. Food habits of big mouth and small mouth buffalow in Liewis and Clark Lake and Missouri River. Trans Amer Fish Soc 96 (1), 70 - 74. http://dx.doi.org/10.1577/1548-8659(1967)96[70:FHOBAS|2.0.CO;2

McKechnie RJ, Fenner RB (1971). Food habits of white sturgeon, Acipenser transmon- tanus, in San Pablo and Suisun bays. California Fish and Game 57, 209-212.

Menon AGK (1999). Check list - fresh water fishes of India. Rec Zool Surv India, Misc. Publ., Occas. Pap. No. 175, $366 \mathrm{pp}$.

Minkin S (1993). Flood control and nutritional consequences of biodiversity of fisheries. Flood Action Plan (FAP) 16, Environmental Study, Dhaka, Bangladesh. 17 pp.

Oo W (2002). Inland fisheries of the Union of Myanmar. In T. Petr and D.B. Swar (eds.) Cold water fisheries in the Trans-Himalayan countries. FAO Fish. Tech. 431 pp.

Petr T (1999). Coldwater fish and fisheries in Bhutan. p. 6-12. In T. Petr (ed.) Fish and fisheries at higher altitudes: Asia. FAO Fish. Tech. Pap. No. 385. FAO, Rome. 304 pp.

Rahman AKA (1989) Freshwater fishes of Bangladesh. Zoological Society of Bangladesh. Department of Zoology, University of Dhaka, Dhaka-1000. 364 pp.

Rahman AKA (2005). Freshwater fishes of Bangladesh. 2nd edition, zoological society of Bangladesh, Department of Zoology, University of Dhaka, Dhaka-1000. 263 pp.

Rahman MM, Hossain MY, Jewel MAS, Rahman MM, Jasmine S, Ohtomi J (2012) Population structure, lengthweight, length-length relationships, condition- and form-factor of the Pool barb Puntius sophore (Hamilton, 1822) (Cyprinidae) from the Chalan Beel, North-Central Bangladesh. Sains Malaysiana, 41(7), 795-802.

Roos N, Wahab MA, Hossain MAR, Thilsted SH (2007) Food and Nutrition Bulletin 28(2) (supplement). The United Nation University.

Shafi M, Quddus MAA (1982) Bangladesher Matshya Sampad (in Bengeli), Bangla Academy, Dhaka. 444 pp.

Shafi M, Quddus MMA (1974). Bionomics of the common punti, Puntivs stigma of Bangladesh. Bangladesh J. Zool., 2:77 - 82.

Shafi M, Quddus MMA (1982). Bangladesher Mathso Sampod (Fisheries of Bangladesh, in Bangali).Bangla Acad, Dhaka. 444 pp.

Stirling, HP (1985). Chemical and biological methods of water analysis for aquaculturists. Institute of Aquaculture, University of Stirling, Stirling. pp. 117.

Talwar PK, Jhingran AG (1991) Inland Fishes of India and Adjacent Countries. vol. 2. A. A. Balkema, Rotterdam. $541 \mathrm{pp}$. 